\title{
DAILY RAINFALL DISAGGREGATION COEFFICIENTS FOR THE DOCE RIVER BASIN, BRAZIL: REGIONAL APPLICABILITY AND THE RETURN PERIOD INFLUENCE
}

\author{
Jéssica B. de M. C. Passos ${ }^{1}$, Demetrius D. da Silva ${ }^{1}$, Rafael P. C. Lima ${ }^{1}$
}

${ }^{1 *}$ Corresponding author. Universidade Federal de Viçosa/ Viçosa - MG, Brasil.

E-mail: jessicabmelo@gmail.com | ORCID ID: https://orcid.org/0000-0002-0473-5384

\author{
KEYWORDS \\ daily rainfall \\ disaggregation \\ method, heavy \\ rainfall, hydrology, \\ pluviometric data, \\ pluviograph gauge \\ station.
}

\begin{abstract}
Alternative methods to the intensity-duration-frequency equations have been used for intense rainfall study in places with no pluviographic data. A pioneering study, by CETESB (1986), established rainfall disaggregation coefficients for Brazil; however, the use of these coefficients take into account neither the rainfall characteristics of the interest locality nor the return period influence in obtaining the precipitation intensities. This study aimed to determine rainfall disaggregation coefficients for Doce river basin; to verify the validity of the regional coefficients use for the entire basin; and to evaluate the return period influence on these coefficients. Data from 19 gauges located in the basin, with rainfall associated with durations of 10 to $1440 \mathrm{~min}$ and return periods of $2,5,10$, 20, 50 and 100 years, were used to obtain the coefficients. Student's t-test was used to assess the regional applicability of these coefficients and the return period influence. The coefficients do not provide regional validity for the entire basin; therefore, regional coefficients were estimated for five hydrologically homogeneous regions, confirming the validity of these coefficients use and the influence of the return period. We conclude that the disaggregation coefficients must be specific for the homogeneous regions and for each return period.
\end{abstract}

\section{INTRODUCTION}

Intensive rainfall is one of the most important meteorological variables in climate studies, as it generates a considerable volume of water in short intervals (Bielenki Júnior et al., 2016; Pereira et al., 2017; Silva et al., 2003). The knowledge of the heavy rainfall characteristics is important to support the planning and dimensioning of hydraulic works, especially hydro-agricultural projects, which are related to the soil and water conservation. Some examples are terracing projects, earth dams, spillways, drainage canals, unpaved roads, among others.

The intensity-duration-frequency equation (IDF) is commonly used to relate rainfall intensity with its duration and annual frequency (Ouarda et al., 2019; Villela \& Mattos, 1975). However, the determination of the IDF ratios for short-term rainfall requires long series of rainfall data and requires a great deal of effort in the tabulation, processing, analysis and interpretation of large numbers of pluviograms data (Bielenki Júnior et al., 2016; Cecílio \& Pruski, 2003; Dorneles et al., 2019). Moreover, the pluviographic series, besides a smaller number, have generally shorter periods and with more failures than the pluviometric series (Back, 2020). This has led to the use of relations that allow the estimation of critical rainfall based on pluviometric data, i.e., using daily rainfall data (Silva \& Oliveira, 2017), since in Brazil, there is an extensive pluviometric monitoring network (Dorneles et al., 2019).

To use daily rainfall data, it is necessary to apply a disaggregation model, from which it is possible to obtain the values of water depths within shorter durations of time from the value of rainfall accumulated in one day (Aragão et al., 2013). CETESB (1986) established the relations among several rainfall durations based on pluviographic data available in the Brazilian territory, which are widely used, such as in the studies of Bielenki Júnior et al. (2016); Dorneles et al. (2019); Pereira et al. (2017); and Silva \& Oliveira (2017).

According to Genovez \& Zuffo (2000), the relations of CETESB (1986) need to be updated because it is an old study based only on records with short data periods from 98

\footnotetext{
${ }^{1}$ Universidade Federal de Viçosa/ Viçosa - MG, Brasil.
} 
localities in Brazil obtained by Pfafstetter (1957). The authors also pointed out that the relations were established for national averages and need to be reviewed for regional averages, considering the predominant rainfall characteristics of the region. Thus, the use of regional coefficients is of great relevance since it allows for the disaggregation of the daily rainfall in any locality of the basin with rain gauge station availability and not only in locations with pluviographic records, which are scarce within the Brazilian territory.

The rainfall disaggregation method assumes that the coefficients are independent from the return period. This fact was evaluated by Silva Neto et al. (2017) who presented the disaggregation coefficient curves as a function of 10 to 100 years return periods for 10 stations in the Tocantins state and noted that the disaggregation coefficients remained practically constant in relation to the return period. However, there were small curvatures, especially in the early return periods, which may compromise the quality of the intense rainfall estimation by the rainfall disaggregation method.

Although rainfall disaggregation works are being developed at the regional level, such as Back et al. (2012) for the Santa Catarina state and Pereira et al. (2014) for the Mato Grosso do Sul state, it is important to take into account the local rainfall characteristics in the disaggregation coefficients determination. Martins et al. (2019) obtained disaggregation coefficients for one rain gauge station located in Caraguatatuba, on the north coast of São Paulo state, and compared the specific coefficients from this station to the average coefficients of São Paulo state. The authors concluded that there were high relative deviation between these disaggregation coefficients, reaching $50 \%$. They highlighted this may cause large variations in micro drainage design for small catchments, where the time of concentration is short.

In this context, the purpose of this work was to determine the daily rainfall disaggregation coefficients for each of the Doce river basin locations with available pluviographic data, to verify the validity of the regional coefficients for the entire basin and to evaluate the influence of return period on the estimated coefficients.

\section{MATERIAL AND METHODS}

The study area comprises the Doce river basin, which is located in the southeast part of Brazil in the tropical region of the southern hemisphere between the parallels $17^{\circ}$ $45^{\prime}$ and $21^{\circ} 15^{\prime} \mathrm{S}$ and the meridians $39^{\circ} 30^{\prime}$ and $43^{\circ} 45^{\prime} \mathrm{W}$. The study area has a drainage area of $86,715 \mathrm{~km}^{2}$, of which $86 \%$ belongs to the Minas Gerais state and the rest to the Espírito Santo state (PIRH-DOCE, 2010). According to the climatic classification of Köppen, the Doce river basin is divided into six climatic zones (Alvares et al., 2013); however, three climatic types predominate in $95 \%$ of its area: i) Aw - tropical climate with dry winter season; ii) Cwa - humid temperate climate with dry winter and hot summer; and iii) Cwb - humid temperate climate with dry winter and temperate summer.

The database used belongs to the hydrometeorological network of the National Water and Sanitation Agency of Brazil (ANA), which consists of records from 19 pluviograph gauge stations located in the Doce River basin (Table 1).

TABLE 1. Pluviograph gauge stations in the Doce river basin.

\begin{tabular}{lcccccc}
\hline \multicolumn{1}{c}{ Pluviograph gauge stations } & Station code & $\begin{array}{c}\text { Latitude } \\
\left({ }^{\circ}\right)\end{array}$ & $\begin{array}{c}\text { Longitude } \\
\left({ }^{\circ}\right)\end{array}$ & $\begin{array}{c}\text { Elevation } \\
(\mathrm{m})\end{array}$ & Analyzed period & Number of years \\
\hline Tumiritinga & 01841011 & -18.9764 & -41.6403 & 135 & $1984-2007$ & 15 \\
Pancas & 01940009 & -19.2203 & -40.8533 & 135 & $1990-2007$ & 14 \\
Caldeirão & 01940020 & -19.9550 & -40.7417 & 750 & $1977-2008$ & 18 \\
Barra do Cuieté - Jusante & 01941005 & -19.0617 & -41.5328 & 121 & $1975-2008$ & 20 \\
Assaraí - Montante & 01941006 & -19.5947 & -41.4581 & 172 & $1991-2008$ & 12 \\
Alto Rio Novo & 01941012 & -19.0592 & -41.0275 & 500 & $1991-2008$ & 11 \\
Dom Cavati & 01942008 & -19.3736 & -42.1050 & 355 & $1977-2008$ & 16 \\
Cenibra & 01942030 & -19.3164 & -42.3961 & 242 & $1990-2008$ & 14 \\
Cachoeira dos Óculos & 01942031 & -19.8158 & -42.4769 & 425 & $1996-2008$ & 9 \\
Naque Velho & 01942032 & -19.1886 & -42.4228 & 240 & $1998-2008$ & 10 \\
Conceição do Mato Dentro & 01943002 & -19.0167 & -43.4442 & 675 & $1986-2008$ & 17 \\
Ferros & 01943003 & -19.2503 & -43.0144 & 470 & $1991-2008$ & 14 \\
Morro do Pilar & 01943025 & -19.2175 & -43.3742 & 560 & $1974-2008$ & 18 \\
Raul Soares - Montante & 02042008 & -20.1036 & -42.4400 & 305 & $1990-2008$ & 13 \\
Ponte Nova - Jusante & 02042018 & -20.3847 & -42.9028 & 350 & $1978-2008$ & 14 \\
Acaiaca - Jusante & 02043009 & -20.3625 & -43.1439 & 423 & $1998-2007$ & 8 \\
Piranga & 02043010 & -20.6906 & -43.2994 & 620 & $1991-2008$ & $1989-2008$ \\
Braz Pires & 02043026 & -20.8475 & -43.2419 & 632 & 780 & $2000-2008$ \\
Desterro de Melo & 02143003 & -21.1492 & -43.5200 & & 9 \\
\hline
\end{tabular}


Because the stations did not provide data for coincident data periods and data were obtained between 1974 and 2008, a base period was not used for the study; however, historical data series containing 8 to 20 years were used to obtain the higher number of information about intense rainfall. The annual data series of maximum rainfall depth associated with the durations of 10, 20, 30, 40, 50 min; 1, 2, 4, 6, 12, $24 \mathrm{~h}$ and $1 \mathrm{~d}$ were obtained from the annual series of pluviographic data for each of the 19 pluviograph gauge stations.

Theoretical probabilistic distributions were used to relate the event magnitudes with their occurrence frequency (Naghettini \& Pinto, 2007). For each duration of analyzed precipitation, the annual series of maximum rainfall depth were subjected to statistical analysis to identify the probabilistic model that best fit the data. The probabilistic distributions of maximum extreme events tested were: Gumbel, Pearson III, LogPearson III and Lognormal at two and three parameters. The statistical criteria adopted to select the model that best fit the data were the standard error pertinent to each probability function and the $95 \%$ confidence interval (Sousa et al., 2009).

\section{Daily rainfall disaggregation}

The daily rainfall disaggregation coefficients (CD) were obtained from the method of relationships among durations, which consists of the ratio of the mean values of precipitated depths of different durations [eq. (1)]. To do so, we used historical series of rainfall depths of 10, 20, 30, 40, $50 \mathrm{~min} ; 1,2,4,6,12,24 \mathrm{~h}$ and $1 \mathrm{~d}$ for each pluviograph gauge station. The coefficients were estimated for the following relationships among different rainfall ratios: $24 \mathrm{~h} / 1 \mathrm{~d}, \quad 12 \mathrm{~h} / 24 \mathrm{~h}, \quad 6 \mathrm{~h} / 24 \mathrm{~h}, \quad 4 \mathrm{~h} / 24 \mathrm{~h}, \quad 2 \mathrm{~h} / 24 \mathrm{~h}, \quad 1 \mathrm{~h} / 24 \mathrm{~h}$, $50 \mathrm{~min} / 1 \mathrm{~h}, \quad 40 \mathrm{~min} / 1 \mathrm{~h}, \quad 30 \mathrm{~min} / 1 \mathrm{~h}, \quad 20 \mathrm{~min} / 30 \mathrm{~min}$, $10 \mathrm{~min} / 30 \mathrm{~min}$.

$$
\mathrm{r}_{\mathrm{t} 1 / \mathrm{t} 2}=\frac{\text { intense rainfall of duration } \mathrm{t}_{1}}{\text { intense rainfall of duration } \mathrm{t}_{2}}
$$

Where:

$r_{t 1 / t 2}$ is the coefficient that characterizes the relation between intense rainfalls of duration $t_{1}$ and $t_{2}$.

The disaggregation coefficients were estimated for each of the 19 locations with pluviograph gauge stations and a single value of disaggregation coefficient for the entire Doce river basin to verify the validity of the use of regional coefficients.

To verify that the regional disaggregation coefficients values representing the entire Doce river basin were statistically equal to the coefficients of each pluviograph gauge station, a statistical hypothesis test
(Student's t-test) was performed at the level of 5\% statistical significance $(\alpha)$. The following hypotheses were tested:

- $\mathrm{H}_{0}$ : the regional disaggregation coefficient of a given rainfall ratio $\mathrm{i}\left(\mathrm{CD}_{\mathrm{i}}\right)$ of the basin is equal to the local disaggregation coefficient of the same rainfall ratio of a pluviograph gauge station $\mathrm{j}\left(\mathrm{CD}_{\mathrm{ij}}\right)$.

- $\mathrm{H}_{\mathrm{a}}$ : the regional disaggregation coefficient of a given rainfall ratio $\mathrm{i}\left(\mathrm{CD}_{\mathrm{i}}\right)$ of the basin is different from the local disaggregation coefficient of the same rainfall ratio of a pluviograph gauge station $\mathrm{j}\left(\mathrm{CD}_{\mathrm{ij}}\right)$.

In cases where the p-value was higher than the level of significance $(\alpha=0.05)$, the hypothesis $\mathrm{H}_{0}$ was not rejected and, therefore, there was no significant difference between the $C D$ values of the Doce river basin and the pluviograph gauge station in analysis.

In preliminary results, we found that the regional coefficients obtained for the entire Doce River basin showed differences when compared to the values obtained in the pluviographic stations. For this reason, we chose to adopt the division of the Doce River basin into five hydrologically homogeneous regions (HHR) in relation to intense rainfall based on the study results of Valverde et al. (2003) for the estimation of mean disaggregation coefficients for each HHR. The same analysis of comparison of means was performed for the average coefficients calculated for each HHR. In this case, the hypotheses $\mathrm{H}_{0}$ and $\mathrm{H}_{\mathrm{a}}$ tested were:

- $\mathrm{H}_{0}$ : the regional disaggregation coefficient of a given rainfall ratio $i$, which is calculated for a hydrologically homogeneous region $\mathrm{k}\left(\mathrm{CD}_{\mathrm{ik}}\right)$, is equal to the local disaggregation coefficient of the same rainfall ratio of a pluviograph gauge station $\mathrm{j}$ located within the homogeneous region $\mathrm{k}\left(\mathrm{CD}_{\mathrm{ij}}\right)$.

- $\mathrm{H}_{\mathrm{a}}$ : the regional disaggregation coefficient of a given rainfall ratio $i$, which is calculated for a hydrologically homogeneous region $\mathrm{k}\left(\mathrm{CD}_{\mathrm{ik}}\right)$, is different from the local disaggregation coefficient of the same rainfall ratio of a pluviograph gauge station $\mathrm{j}$ located within the homogeneous region $\mathrm{k}\left(\mathrm{CD}_{\mathrm{ij}}\right)$.

Figure 1 shows the location of the pluviograph gauge stations of the study area, as well as the HHR to which they belong, according to Valverde et al. (2003). Out of 31 pluviograph gauge stations used in the study of Valverde et al. (2003) including data from National Meteorological Institute (INMET) and Companhia Energética de Minas Gerais (CEMIG) network, 19 stations were used in this study. It is worth noting that there was no delimitation of the HHR itself, but rather the division of the regions was according to the function of the stations that manifested hydrologically homogeneous behavior. 


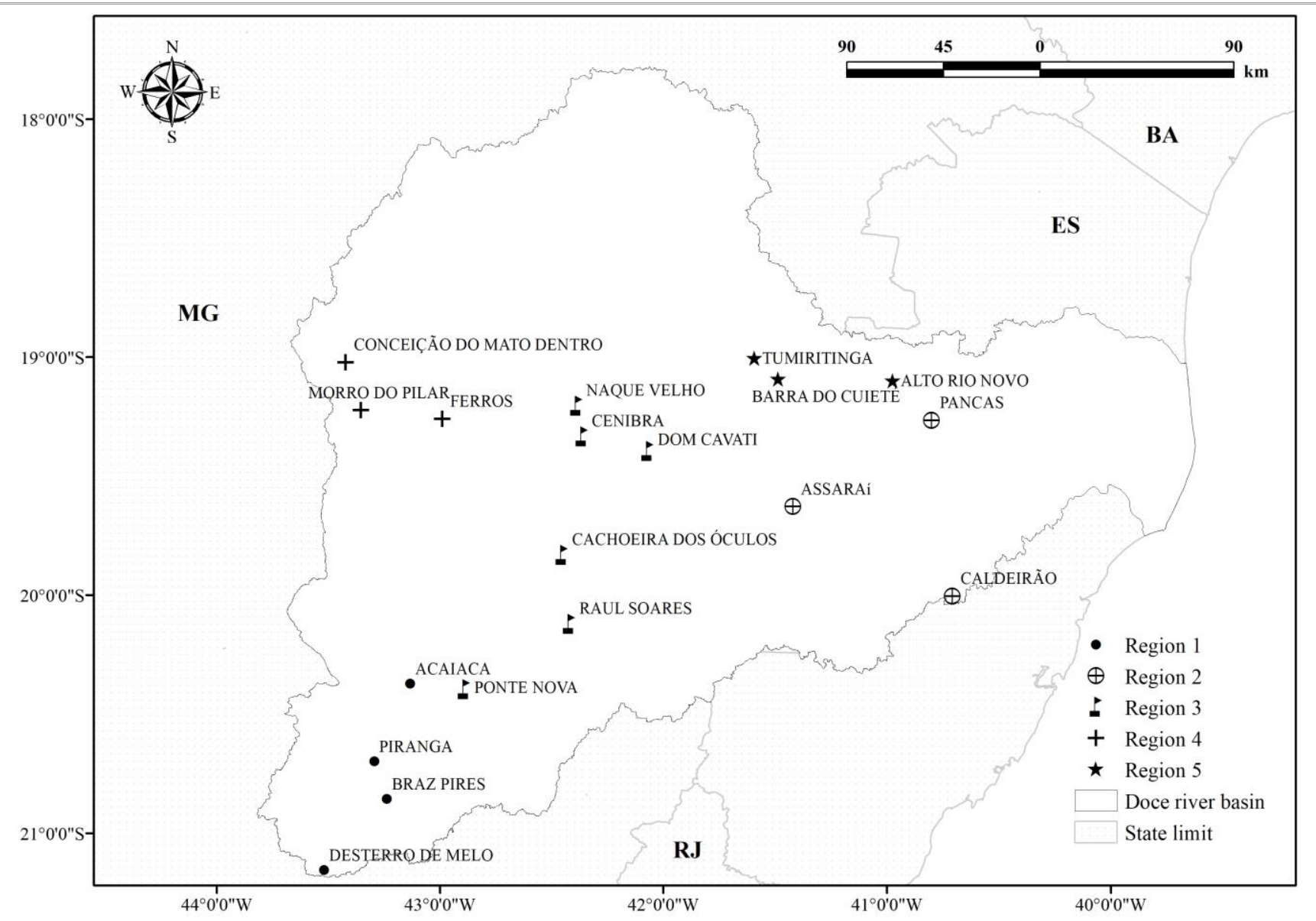

FIGURE 1. Location of the pluviograph gauge station used in the study with the respective framing in the five hydrologically homogeneous regions proposed by Valverde et al. (2003).

\section{Return period influence on the disaggregation coefficients}

To evaluate the influence of the return period on the values of the disaggregation coefficients, means of the series of maximum rainfall depth with different durations associated with the return periods of 2, 5, 10, 20, 50 and 100 years were used to estimate these coefficients. Coefficients of disaggregation and return periods were graphically represented, and the behavior of the linear trend functions was analyzed since the values of the disaggregation coefficients are independent of the return period according to CETESB (1986).

Influence of the return periods on the rainfall disaggregation coefficients was verified using Student's ttest, which tested the null hypothesis $\left(\mathrm{H}_{0}\right)$ for the slope coefficient $\left(\beta_{1}\right)$, at the level of $5 \%$ statistical significance, since $\beta_{1}$ equal to zero indicates that the generated curves are parallel to the abscissa.

Thus, the null hypothesis $\left(\mathrm{H}_{0}\right)$ and alternative hypothesis $\left(\mathrm{H}_{\mathrm{a}}\right)$ tested were:

- $\mathrm{H}_{0}: \beta_{1}=0$

- $\mathrm{H}_{\mathrm{a}}: \beta_{1} \neq 0$.

Equation 2 presents the test statistic t:

$\mathrm{t}=\frac{\beta_{1}}{\sqrt{\widehat{\mathrm{V}}\left(\beta_{1}\right)}}$
Where:

$\beta_{1}$ is the slope coefficient, and

$\widehat{\mathrm{V}}$ is the variance.

\section{RESULTS AND DISCUSSION}

Of the five probabilistic distributions tested for the historical series of precipitation associated with different durations, Lognormal for two and three parameters fit better to the data of most pluviograph gauge stations, as well as in the study by Caldeira et al. (2015).

\section{Daily rainfall disaggregation}

The rainfall disaggregation coefficients for each pluviograph gauge station and the coefficients means for the rainfall ratios that represent the entire hydrographic basin are presented in Table 2. In general, the lower values of standard deviation, coefficient of variation (CV) and amplitude show that the coefficients did not vary significantly. Silva Neto et al. (2017) obtained a similar result for the Tocantins state, where $\mathrm{CV}$ for the disaggregation coefficients were obtained below $4.04 \%$, indicating small variation among the estimated coefficients. 
TABLE 2. Disaggregation coefficients for the 19 pluviograph gauge stations and average disaggregation coefficients for the entire Doce river basin.

\begin{tabular}{|c|c|c|c|c|c|c|c|c|c|c|c|}
\hline \multirow[b]{2}{*}{ Pluviograph gauge stations } & \multicolumn{11}{|c|}{ Rainfall disaggregation coefficients } \\
\hline & $\begin{array}{l}24 \mathrm{~h} \\
/ 1 \mathrm{~d}\end{array}$ & $\begin{array}{c}12 \mathrm{~h} \\
124 \mathrm{~h}\end{array}$ & $\begin{array}{c}6 \mathrm{~h} \\
124 \mathrm{~h} \\
\end{array}$ & $\begin{array}{c}4 \mathrm{~h} \\
124 \mathrm{~h} \\
\end{array}$ & $\begin{array}{c}2 \mathrm{~h} \\
124 \mathrm{~h} \\
\end{array}$ & $\begin{array}{c}1 \mathrm{~h} \\
/ 24 \mathrm{~h} \\
\end{array}$ & $\begin{array}{c}50 \mathrm{~min} \\
/ 1 \mathrm{~h}\end{array}$ & $\begin{array}{c}40 \mathrm{~min} \\
/ 1 \mathrm{~h}\end{array}$ & $\begin{array}{c}30 \mathrm{~min} \\
/ 1 \mathrm{~h}\end{array}$ & $\begin{array}{l}20 \mathrm{~min} \\
130 \mathrm{~min}\end{array}$ & $\begin{array}{l}10 \mathrm{~min} \\
130 \mathrm{~min}\end{array}$ \\
\hline Tumiritinga & 1.039 & 0.915 & 0.866 & 0.798 & 0.670 & 0.570 & 0.930 & 0.866 & 0.753 & 0.860 & 0.609 \\
\hline Pancas & 1.104 & 0.896 & 0.852 & 0.818 & 0.712 & 0.577 & 0.964 & 0.860 & 0.751 & 0.881 & 0.602 \\
\hline Caldeirão & 1.108 & 0.872 & 0.770 & 0.714 & 0.612 & 0.494 & 0.919 & 0.854 & 0.760 & 0.872 & 0.596 \\
\hline Barra do Cuieté & 1.103 & 0.909 & 0.871 & 0.826 & 0.701 & 0.608 & 0.939 & 0.871 & 0.797 & 0.816 & 0.578 \\
\hline Assaraí & 1.104 & 0.853 & 0.821 & 0.780 & 0.680 & 0.593 & 0.983 & 0.924 & 0.842 & 0.812 & 0.534 \\
\hline Alto Rio Novo & 1.037 & 0.965 & 0.851 & 0.797 & 0.718 & 0.622 & 0.943 & 0.859 & 0.763 & 0.880 & 0.620 \\
\hline Dom Cavati & 1.099 & 0.851 & 0.791 & 0.763 & 0.631 & 0.553 & 0.961 & 0.892 & 0.745 & 0.845 & 0.594 \\
\hline Cenibra & 1.053 & 0.915 & 0.827 & 0.754 & 0.646 & 0.513 & 0.969 & 0.862 & 0.757 & 0.838 & 0.628 \\
\hline Cachoeira dos Óculos & 1.065 & 0.914 & 0.845 & 0.785 & 0.632 & 0.533 & 0.954 & 0.917 & 0.825 & 0.830 & 0.621 \\
\hline Naque Velho & 1.035 & 0.926 & 0.866 & 0.818 & 0.649 & 0.501 & 0.938 & 0.851 & 0.732 & 0.893 & 0.572 \\
\hline Conceição do Mato Dentro & 1.045 & 0.897 & 0.777 & 0.719 & 0.621 & 0.497 & 0.955 & 0.898 & 0.807 & 0.837 & 0.596 \\
\hline Ferros & 1.073 & 0.872 & 0.769 & 0.733 & 0.619 & 0.496 & 0.959 & 0.911 & 0.817 & 0.831 & 0.567 \\
\hline Morro do Pilar & 1.084 & 0.844 & 0.772 & 0.693 & 0.584 & 0.500 & 0.955 & 0.872 & 0.805 & 0.827 & 0.600 \\
\hline Raul Soares & 1.077 & 0.883 & 0.804 & 0.760 & 0.654 & 0.529 & 0.904 & 0.831 & 0.741 & 0.832 & 0.530 \\
\hline Ponte Nova & 1.069 & 0.912 & 0.856 & 0.808 & 0.681 & 0.548 & 0.922 & 0.841 & 0.721 & 0.809 & 0.569 \\
\hline Acaiaca & 1.059 & 0.907 & 0.828 & 0.764 & 0.645 & 0.589 & 0.936 & 0.871 & 0.822 & 0.803 & 0.615 \\
\hline Piranga & 1.125 & 0.856 & 0.756 & 0.684 & 0.599 & 0.530 & 0.943 & 0.866 & 0.766 & 0.815 & 0.643 \\
\hline Braz Pires & 1.102 & 0.853 & 0.781 & 0.737 & 0.665 & 0.560 & 0.969 & 0.901 & 0.799 & 0.880 & 0.583 \\
\hline Desterro de Melo & 1.147 & 0.831 & 0.755 & 0.698 & 0.635 & 0.570 & 0.937 & 0.849 & 0.744 & 0.821 & 0.571 \\
\hline Mean of the basin & 1.080 & 0.888 & 0.814 & 0.760 & 0.650 & 0.547 & 0.946 & 0.873 & 0.776 & 0.841 & 0.591 \\
\hline Standard deviation & 0.032 & 0.035 & 0.041 & 0.045 & 0.037 & 0.041 & 0.020 & 0.026 & 0.036 & 0.028 & 0.030 \\
\hline $\mathrm{CV}(\%)$ & 2.948 & 3.892 & 5.040 & 5.932 & 5.687 & 7.427 & 2.097 & 3.010 & 4.665 & 3.342 & 5.053 \\
\hline Amplitude & 0.112 & 0.134 & 0.116 & 0.142 & 0.134 & 0.127 & 0.080 & 0.093 & 0.121 & 0.090 & 0.113 \\
\hline
\end{tabular}

For the p-value results obtained by comparing the average coefficients representing the entire basin with the data of each pluviograph gauge station (Table 3), only for the rainfall ratios of $2 \mathrm{~h} / 24 \mathrm{~h}$ and $1 \mathrm{~h} / 24 \mathrm{~h}$ all the coefficients were statistically equal to the disaggregation coefficients of the entire basin. Statistical differences in other rainfall ratios indicate that the use of regional disaggregation coefficients for the purposes of representation of the entire Doce river basin is not valid.

In Table 3, the results in bold refer to p-values lower than the level of significance $(\alpha=0.05)$. 
TABLE 3. p-values obtained by Student's t-test for comparison between the average rainfall disaggregation coefficients of the basin and the coefficients of each of the 19 pluviograph gauge stations.

\begin{tabular}{|c|c|c|c|c|c|c|c|c|c|c|c|}
\hline \multicolumn{12}{|c|}{ p-value (Student's t-test) } \\
\hline \multirow[b]{2}{*}{ Pluviograph gauge stations } & \multicolumn{11}{|c|}{ Rainfall disaggregation coefficients } \\
\hline & $\begin{array}{l}24 \mathrm{~h} \\
/ 1 \mathrm{~d}\end{array}$ & $\begin{array}{c}12 \mathrm{~h} \\
124 \mathrm{~h} \\
\end{array}$ & $\begin{array}{c}6 \mathrm{~h} \\
/ 24 \mathrm{~h} \\
\end{array}$ & $\begin{array}{c}4 \mathrm{~h} \\
/ 24 \mathrm{~h} \\
\end{array}$ & $\begin{array}{c}2 \mathrm{~h} \\
124 \mathrm{~h}\end{array}$ & $\begin{array}{c}1 \mathrm{~h} \\
/ 24 \mathrm{~h}\end{array}$ & $\begin{array}{c}50 \mathrm{~min} \\
/ 1 \mathrm{~h}\end{array}$ & $\begin{array}{c}40 \mathrm{~min} \\
/ 1 \mathrm{~h}\end{array}$ & $\begin{array}{c}\text { 30min } \\
/ 1 \mathrm{~h}\end{array}$ & $\begin{array}{c}20 \mathrm{~min} \\
130 \mathrm{~min}\end{array}$ & $\begin{array}{c}10 \mathrm{~min} \\
130 \mathrm{~min}\end{array}$ \\
\hline Tumiritinga & 0.00 & 0.21 & 0.11 & 0.27 & 0.60 & 0.53 & 0.35 & 0.70 & 0.40 & 0.44 & 0.62 \\
\hline Pancas & 0.51 & 0.77 & 0.18 & 0.09 & 0.09 & 0.37 & 0.15 & 0.56 & 0.37 & 0.08 & 0.64 \\
\hline Caldeirão & 0.48 & 0.60 & 0.20 & 0.21 & 0.41 & 0.18 & 0.12 & 0.48 & 0.64 & 0.23 & 0.87 \\
\hline Barra do Cuieté & 0.48 & 0.37 & 0.04 & 0.03 & 0.22 & 0.19 & 0.64 & 0.92 & 0.49 & 0.33 & 0.63 \\
\hline Assaraí & 0.70 & 0.34 & 0.84 & 0.57 & 0.30 & 0.23 & 0.00 & 0.01 & 0.01 & 0.27 & 0.03 \\
\hline Alto Rio Novo & 0.01 & $\mathbf{0 . 0 0}$ & 0.30 & 0.37 & 0.13 & 0.11 & 0.80 & 0.59 & 0.62 & 0.16 & 0.43 \\
\hline Dom Cavati & 0.24 & 0.21 & 0.43 & 0.93 & 0.60 & 0.84 & 0.29 & 0.43 & 0.21 & 0.93 & 0.92 \\
\hline Cenibra & 0.19 & 0.18 & 0.61 & 0.82 & 0.90 & 0.31 & 0.12 & 0.62 & 0.59 & 0.94 & 0.20 \\
\hline Cachoeira dos Óculos & 0.37 & 0.14 & 0.16 & 0.34 & 0.55 & 0.65 & 0.55 & 0.01 & 0.01 & 0.57 & 0.25 \\
\hline Naque Velho & 0.00 & 0.06 & 0.04 & 0.05 & 0.97 & 0.24 & 0.67 & 0.38 & 0.21 & 0.01 & 0.50 \\
\hline Conceição do Mato Dentro & 0.08 & 0.66 & 0.35 & 0.33 & 0.45 & 0.10 & 0.45 & 0.21 & 0.20 & 0.85 & 0.82 \\
\hline Ferros & 0.76 & 0.46 & 0.19 & 0.45 & 0.38 & 0.08 & 0.33 & 0.09 & 0.21 & 0.68 & 0.33 \\
\hline Morro do Pilar & 0.89 & 0.15 & 0.23 & 0.04 & 0.07 & 0.19 & 0.55 & 0.96 & 0.17 & 0.47 & 0.76 \\
\hline Raul Soares & 0.95 & 0.89 & 0.82 & 0.98 & 0.93 & 0.65 & 0.04 & 0.08 & 0.37 & 0.83 & 0.03 \\
\hline Ponte Nova & 0.74 & 0.34 & 0.19 & 0.12 & 0.30 & 0.96 & 0.21 & 0.21 & 0.02 & 0.21 & 0.43 \\
\hline Acaiaca & 0.31 & 0.45 & 0.59 & 0.91 & 0.87 & 0.32 & 0.58 & 0.92 & 0.20 & 0.07 & 0.35 \\
\hline Piranga & 0.39 & 0.34 & 0.19 & 0.12 & 0.23 & 0.65 & 0.87 & 0.71 & 0.68 & 0.19 & 0.07 \\
\hline Braz Pires & 0.49 & 0.25 & 0.36 & 0.43 & 0.60 & 0.61 & 0.11 & 0.23 & 0.40 & 0.22 & 0.74 \\
\hline Desterro de Melo & 0.25 & 0.07 & 0.07 & 0.13 & 0.72 & 0.57 & 0.38 & 0.12 & 0.19 & 0.35 & 0.51 \\
\hline
\end{tabular}

Similar results are achieved by Martins et al. (2019), who compared disaggregation coefficients established for one pluviograph gauge station located in Caraguatatuba city (SP) with coefficients of other cities of São Paulo state. For short durations, specifically $10 \mathrm{~min} / 24 \mathrm{~h}$, the deviation in relation to the average of other cities exceeds $100 \%$, decreasing, however, with the raising of the duration. Therefore, the authors conclude that the establishing of average rainfall coefficients for short durations may cause completely wrong intensities.
The proof of the difference in the rainfall ratios of different durations, in different locations, indicates that the coefficients generated by CETESB (1986) can be sources of inconsistencies in the application of the methodology of daily rainfall disaggregation (Abreu, 2018).

Since the regional disaggregation coefficients representing the entire Doce river basin were not feasible for use in the daily rainfall disaggregation study, the average disaggregation coefficients were determined for the five HHR of the Doce river basin (Table 4). 
TABLE 4. Average disaggregation coefficients for the five hydrologically homogeneous regions (HHR) of the Doce river basin.

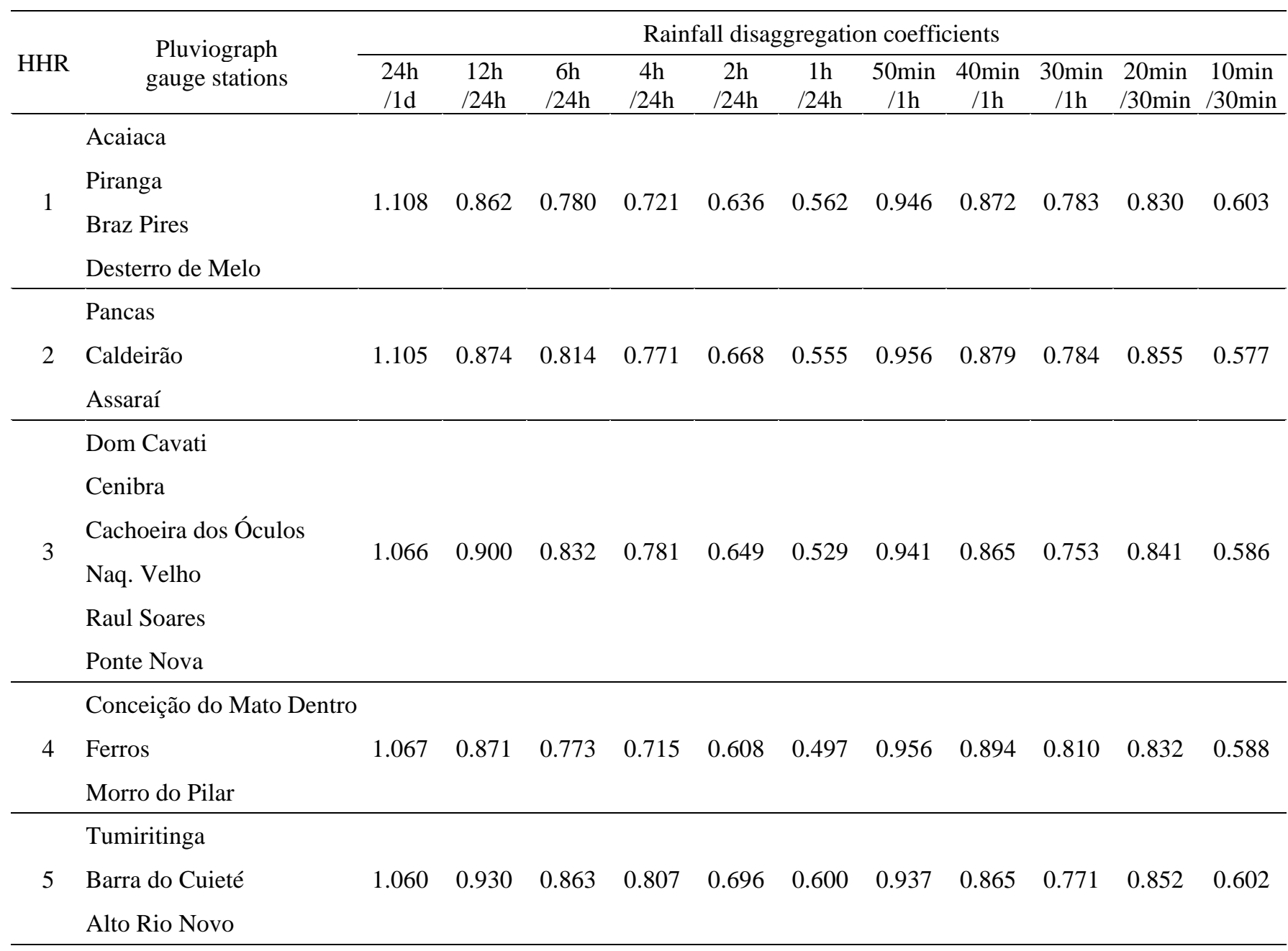

The p-value results, which were obtained by comparing the coefficients of each HHR with the data of each pluviograph gauge station (Table 5), show that all the rainfall disaggregation coefficients were statistically equal in regions $1,2,4$ and 5 . Only two pluviograph gauge stations in region 3 showed that the rainfall ratios of $24 \mathrm{~h} / 1 \mathrm{~d}$ and $30 \mathrm{~min} / 1 \mathrm{~h}$ were different from the average of the region. 
TABLE 5. p-values obtained by Student's t-test for comparison between the average rainfall disaggregation coefficients of the five hydrologically homogeneous regions and the coefficients of each of the 19 pluviograph gauge stations of the Doce river basin.

\begin{tabular}{|c|c|c|c|c|c|c|c|c|c|c|c|c|}
\hline \multicolumn{13}{|c|}{ p-value (Student's t-test) } \\
\hline \multirow[b]{2}{*}{ HHR } & \multirow[b]{2}{*}{ Pluviograph gauge stations } & \multicolumn{11}{|c|}{ Rainfall disaggregation coefficients } \\
\hline & & $\begin{array}{l}24 \mathrm{~h} \\
/ 1 \mathrm{~d}\end{array}$ & $\begin{array}{l}12 \mathrm{~h} \\
/ 24 \mathrm{~h}\end{array}$ & $\begin{array}{c}6 \mathrm{~h} \\
124 \mathrm{~h} \\
\end{array}$ & $\begin{array}{c}4 \mathrm{~h} \\
/ 24 \mathrm{~h} \\
\end{array}$ & $\begin{array}{c}2 \mathrm{~h} \\
/ 24 \mathrm{~h}\end{array}$ & $\begin{array}{c}1 \mathrm{~h} \\
/ 24 \mathrm{~h}\end{array}$ & $\begin{array}{c}50 \mathrm{~min} \\
/ 1 \mathrm{~h}\end{array}$ & $\begin{array}{c}40 \mathrm{~min} \\
/ 1 \mathrm{~h}\end{array}$ & $\begin{array}{l}\text { 30min } \\
/ 1 \mathrm{~h}\end{array}$ & $\begin{array}{l}20 \mathrm{~min} \\
130 \mathrm{~min}\end{array}$ & $\begin{array}{l}10 \mathrm{~min} \\
130 \mathrm{~min}\end{array}$ \\
\hline \multirow{4}{*}{1} & Acaiaca & 0.25 & 0.39 & 0.39 & 0.44 & 0.91 & 0.78 & 0.80 & 0.99 & 0.61 & 0.53 & 0.83 \\
\hline & Piranga & 0.89 & 0.94 & 0.80 & 0.73 & 0.69 & 0.68 & 0.94 & 0.89 & 0.74 & 0.73 & 0.51 \\
\hline & Braz Pires & 0.93 & 0.89 & 0.99 & 0.77 & 0.63 & 0.97 & 0.44 & 0.55 & 0.77 & 0.47 & 0.70 \\
\hline & Desterro de Melo & 0.77 & 0.64 & 0.70 & 0.79 & 0.99 & 0.93 & 0.61 & 0.43 & 0.44 & 0.84 & 0.64 \\
\hline \multirow{3}{*}{2} & Pancas & 0.99 & 0.73 & 0.59 & 0.56 & 0.63 & 0.80 & 0.78 & 0.74 & 0.63 & 0.64 & 0.68 \\
\hline & Caldeirão & 0.98 & 0.98 & 0.60 & 0.54 & 0.63 & 0.53 & 0.40 & 0.71 & 0.78 & 0.79 & 0.82 \\
\hline & Assaraí & 0.99 & 0.82 & 0.94 & 0.91 & 0.86 & 0.69 & 0.13 & 0.35 & 0.34 & 0.52 & 0.50 \\
\hline \multirow{6}{*}{3} & Dom Cavati & 0.34 & 0.34 & 0.41 & 0.69 & 0.78 & 0.68 & 0.42 & 0.53 & 0.84 & 0.96 & 0.86 \\
\hline & Cenibra & 0.70 & 0.65 & 0.93 & 0.58 & 0.96 & 0.77 & 0.27 & 0.93 & 0.96 & 0.97 & 0.40 \\
\hline & Cachoeira dos Óculos & 0.95 & 0.59 & 0.69 & 0.92 & 0.74 & 0.95 & 0.56 & 0.09 & 0.02 & 0.74 & 0.44 \\
\hline & Naque Velho & 0.04 & 0.40 & 0.40 & 0.43 & 1.00 & 0.67 & 0.92 & 0.75 & 0.73 & 0.14 & 0.78 \\
\hline & Raul Soares & 0.89 & 0.78 & 0.72 & 0.79 & 0.95 & 0.99 & 0.31 & 0.41 & 0.86 & 0.90 & 0.25 \\
\hline & Ponte Nova & 0.97 & 0.78 & 0.66 & 0.60 & 0.54 & 0.75 & 0.57 & 0.59 & 0.40 & 0.47 & 0.74 \\
\hline \multirow{3}{*}{4} & Conceição do Mato Dentro & 0.64 & 0.57 & 0.96 & 0.97 & 0.89 & 0.99 & 0.98 & 0.93 & 0.96 & 0.93 & 0.88 \\
\hline & Ferros & 0.93 & 0.99 & 0.97 & 0.84 & 0.90 & 0.98 & 0.94 & 0.75 & 0.93 & 0.99 & 0.73 \\
\hline & Morro do Pilar & 0.76 & 0.72 & 0.99 & 0.78 & 0.79 & 0.98 & 0.96 & 0.73 & 0.93 & 0.93 & 0.87 \\
\hline \multirow{3}{*}{5} & Tumiritinga & 0.48 & 0.77 & 0.97 & 0.92 & 0.78 & 0.76 & 0.87 & 0.99 & 0.79 & 0.90 & 0.94 \\
\hline & Barra do Cuieté & 0.59 & 0.72 & 0.89 & 0.80 & 0.96 & 0.95 & 0.97 & 0.92 & 0.73 & 0.58 & 0.72 \\
\hline & Alto Rio Novo & 0.54 & 0.28 & 0.90 & 0.92 & 0.85 & 0.86 & 0.87 & 0.92 & 0.90 & 0.69 & 0.85 \\
\hline
\end{tabular}

According to the results obtained, the use of regional disaggregation coefficients representing each of the five hydrologically homogeneous regions of the Doce river basin is validated. Martins et al. (2019) affirm that the employment of the disaggregation coefficients in climatically similar regions is of great value for hydraulic engineering projects.

Genovez \& Zuffo (2000) concluded that the method of rainfall ratios of different durations has regional validity which supports and corroborates the results obtained in this study. The authors also state that, although the average values of these relationships are close to the several parts of the world, it is convenient to establish new coefficients, related to the local characteristics of microclimates in order to characterize intense rainfall of a certain locality.

It is noteworthy that the short historical series of precipitation are subject to statistical fluctuations, which can result in "false" maximum rainfall (Martins et al., 2019).
Therefore, the development of rainfall ratios of different durations with the use of longer historical series, may favor the development of methods for disaggregating daily rainfall (Abreu, 2018).

The results of this work has great relevance for heavy rainfall studies, especially in the Doce river basin. Since the pluviometric data are available throughout the basin with longer series and fewer failures, the adoption of average disaggregation coefficients representing a hydrologically homogeneous region make it possible to study heavy rainfall in a simple and comprehensive way.

\section{Return period influence on the disaggregation coefficients}

The rainfall disaggregation coefficients associated with the return periods of 2, 5, 10, 20, 50 and 100 years, for each hydrologically homogeneous region are shown in Table 6. 
TABLE 6. Disaggregation coefficients associated with the return periods of 2, 5, 10, 20, 50 and 100 years for five hydrologically homogeneous regions (HHR) of the Doce River basin.

\begin{tabular}{|c|c|c|c|c|c|c|c|c|c|c|c|c|}
\hline \multirow[b]{2}{*}{ HHR } & \multirow{2}{*}{$\begin{array}{c}\mathrm{T} \\
\text { (years) }\end{array}$} & \multicolumn{11}{|c|}{ Rainfall disaggregation coefficients } \\
\hline & & $\begin{array}{l}24 \mathrm{~h} \\
/ 1 \mathrm{~d}\end{array}$ & $\begin{array}{c}12 \mathrm{~h} \\
124 \mathrm{~h}\end{array}$ & $\begin{array}{c}6 \mathrm{~h} \\
/ 24 \mathrm{~h} \\
\end{array}$ & $\begin{array}{c}4 \mathrm{~h} \\
/ 24 \mathrm{~h}\end{array}$ & $\begin{array}{c}2 \mathrm{~h} \\
/ 24 \mathrm{~h}\end{array}$ & $\begin{array}{c}1 \mathrm{~h} \\
124 \mathrm{~h}\end{array}$ & $\begin{array}{c}50 \mathrm{~min} \\
/ 1 \mathrm{~h}\end{array}$ & $\begin{array}{c}40 \mathrm{~min} \\
/ 1 \mathrm{~h}\end{array}$ & $\begin{array}{l}\text { 30min } \\
/ 1 \mathrm{~h}\end{array}$ & $\begin{array}{l}20 \mathrm{~min} \\
130 \mathrm{~min}\end{array}$ & $\begin{array}{l}10 \mathrm{~min} \\
130 \mathrm{~min}\end{array}$ \\
\hline \multirow{7}{*}{1} & 2 & 1.093 & 0.854 & 0.771 & 0.717 & 0.628 & 0.552 & 0.941 & 0.867 & 0.772 & 0.825 & 0.599 \\
\hline & 5 & 1.083 & 0.841 & 0.751 & 0.691 & 0.595 & 0.519 & 0.933 & 0.860 & 0.754 & 0.837 & 0.585 \\
\hline & 10 & 1.081 & 0.835 & 0.740 & 0.675 & 0.578 & 0.503 & 0.931 & 0.856 & 0.746 & 0.843 & 0.577 \\
\hline & 20 & 1.081 & 0.831 & 0.731 & 0.661 & 0.564 & 0.491 & 0.929 & 0.853 & 0.741 & 0.848 & 0.569 \\
\hline & 50 & 1.089 & 0.826 & 0.722 & 0.644 & 0.549 & 0.477 & 0.929 & 0.850 & 0.735 & 0.854 & 0.560 \\
\hline & 100 & 1.095 & 0.822 & 0.716 & 0.633 & 0.539 & 0.469 & 0.929 & 0.848 & 0.732 & 0.858 & 0.554 \\
\hline & Mean & 1.087 & 0.835 & 0.738 & 0.670 & 0.576 & 0.502 & 0.932 & 0.856 & 0.747 & 0.844 & 0.574 \\
\hline \multirow{7}{*}{2} & 2 & 1.087 & 0.865 & 0.804 & 0.751 & 0.653 & 0.535 & 0.948 & 0.869 & 0.780 & 0.842 & 0.560 \\
\hline & 5 & 1.053 & 0.911 & 0.829 & 0.768 & 0.655 & 0.530 & 0.929 & 0.851 & 0.748 & 0.837 & 0.578 \\
\hline & 10 & 1.039 & 0.934 & 0.842 & 0.780 & 0.656 & 0.527 & 0.923 & 0.845 & 0.730 & 0.837 & 0.592 \\
\hline & 20 & 1.028 & 0.953 & 0.853 & 0.791 & 0.657 & 0.525 & 0.919 & 0.841 & 0.714 & 0.839 & 0.606 \\
\hline & 50 & 1.019 & 0.974 & 0.865 & 0.806 & 0.659 & 0.523 & 0.915 & 0.838 & 0.697 & 0.842 & 0.623 \\
\hline & 100 & 1.018 & 0.989 & 0.874 & 0.816 & 0.661 & 0.522 & 0.914 & 0.837 & 0.686 & 0.844 & 0.636 \\
\hline & Mean & 1.041 & 0.938 & 0.845 & 0.786 & 0.657 & 0.527 & 0.925 & 0.847 & 0.726 & 0.840 & 0.599 \\
\hline \multirow{7}{*}{3} & 2 & 1.045 & 0.913 & 0.839 & 0.793 & 0.653 & 0.531 & 0.935 & 0.859 & 0.744 & 0.826 & 0.571 \\
\hline & 5 & 1.041 & 0.928 & 0.853 & 0.789 & 0.631 & 0.512 & 0.934 & 0.850 & 0.733 & 0.828 & 0.578 \\
\hline & 10 & 1.039 & 0.936 & 0.861 & 0.786 & 0.619 & 0.500 & 0.935 & 0.846 & 0.728 & 0.831 & 0.584 \\
\hline & 20 & 1.037 & 0.943 & 0.868 & 0.783 & 0.608 & 0.490 & 0.937 & 0.843 & 0.724 & 0.835 & 0.591 \\
\hline & 50 & 1.036 & 0.951 & 0.876 & 0.779 & 0.596 & 0.479 & 0.940 & 0.840 & 0.719 & 0.839 & 0.599 \\
\hline & 100 & 1.036 & 0.956 & 0.881 & 0.776 & 0.588 & 0.471 & 0.942 & 0.838 & 0.716 & 0.843 & 0.606 \\
\hline & Mean & 1.039 & 0.938 & 0.863 & 0.785 & 0.616 & 0.497 & 0.937 & 0.846 & 0.727 & 0.834 & 0.588 \\
\hline \multirow{7}{*}{4} & 2 & 1.063 & 0.865 & 0.767 & 0.719 & 0.592 & 0.480 & 0.970 & 0.888 & 0.802 & 0.831 & 0.580 \\
\hline & 5 & 1.070 & 0.863 & 0.783 & 0.725 & 0.599 & 0.481 & 0.959 & 0.887 & 0.797 & 0.836 & 0.583 \\
\hline & 10 & 1.073 & 0.862 & 0.787 & 0.720 & 0.602 & 0.482 & 0.946 & 0.887 & 0.794 & 0.837 & 0.584 \\
\hline & 20 & 1.076 & 0.861 & 0.790 & 0.713 & 0.604 & 0.483 & 0.934 & 0.887 & 0.793 & 0.838 & 0.586 \\
\hline & 50 & 1.079 & 0.861 & 0.791 & 0.701 & 0.605 & 0.483 & 0.917 & 0.887 & 0.790 & 0.838 & 0.587 \\
\hline & 100 & 1.081 & 0.861 & 0.791 & 0.692 & 0.606 & 0.484 & 0.905 & 0.888 & 0.789 & 0.837 & 0.588 \\
\hline & Mean & 1.074 & 0.862 & 0.785 & 0.712 & 0.601 & 0.482 & 0.938 & 0.887 & 0.794 & 0.836 & 0.585 \\
\hline \multirow{7}{*}{5} & 2 & 1.039 & 0.946 & 0.855 & 0.802 & 0.678 & 0.586 & 0.918 & 0.857 & 0.759 & 0.846 & 0.581 \\
\hline & 5 & 1.040 & 0.943 & 0.851 & 0.777 & 0.661 & 0.573 & 0.920 & 0.855 & 0.757 & 0.854 & 0.560 \\
\hline & 10 & 1.047 & 0.934 & 0.849 & 0.764 & 0.653 & 0.563 & 0.929 & 0.857 & 0.756 & 0.858 & 0.553 \\
\hline & 20 & 1.057 & 0.923 & 0.848 & 0.753 & 0.647 & 0.554 & 0.940 & 0.860 & 0.757 & 0.861 & 0.548 \\
\hline & 50 & 1.072 & 0.908 & 0.846 & 0.740 & 0.641 & 0.543 & 0.956 & 0.864 & 0.757 & 0.864 & 0.545 \\
\hline & 100 & 1.083 & 0.898 & 0.844 & 0.731 & 0.637 & 0.536 & 0.969 & 0.868 & 0.758 & 0.866 & 0.543 \\
\hline & Mean & 1.056 & 0.925 & 0.849 & 0.761 & 0.653 & 0.559 & 0.938 & 0.860 & 0.757 & 0.858 & 0.555 \\
\hline
\end{tabular}

Figure 2 indicates that the curves generated from the rainfall disaggregation coefficients and the return periods do not show great oscillations. Greater distortions can be noticed at the beginning of the curves for the 2 years return period. Similar behavior was observed in the study of Silva
Neto et al. (2017) for 10 pluviograph gauge stations in the Tocantins state. The authors found small curvatures for small return periods while the values of the disaggregation coefficients remained almost constant for more than 10 years return periods. 

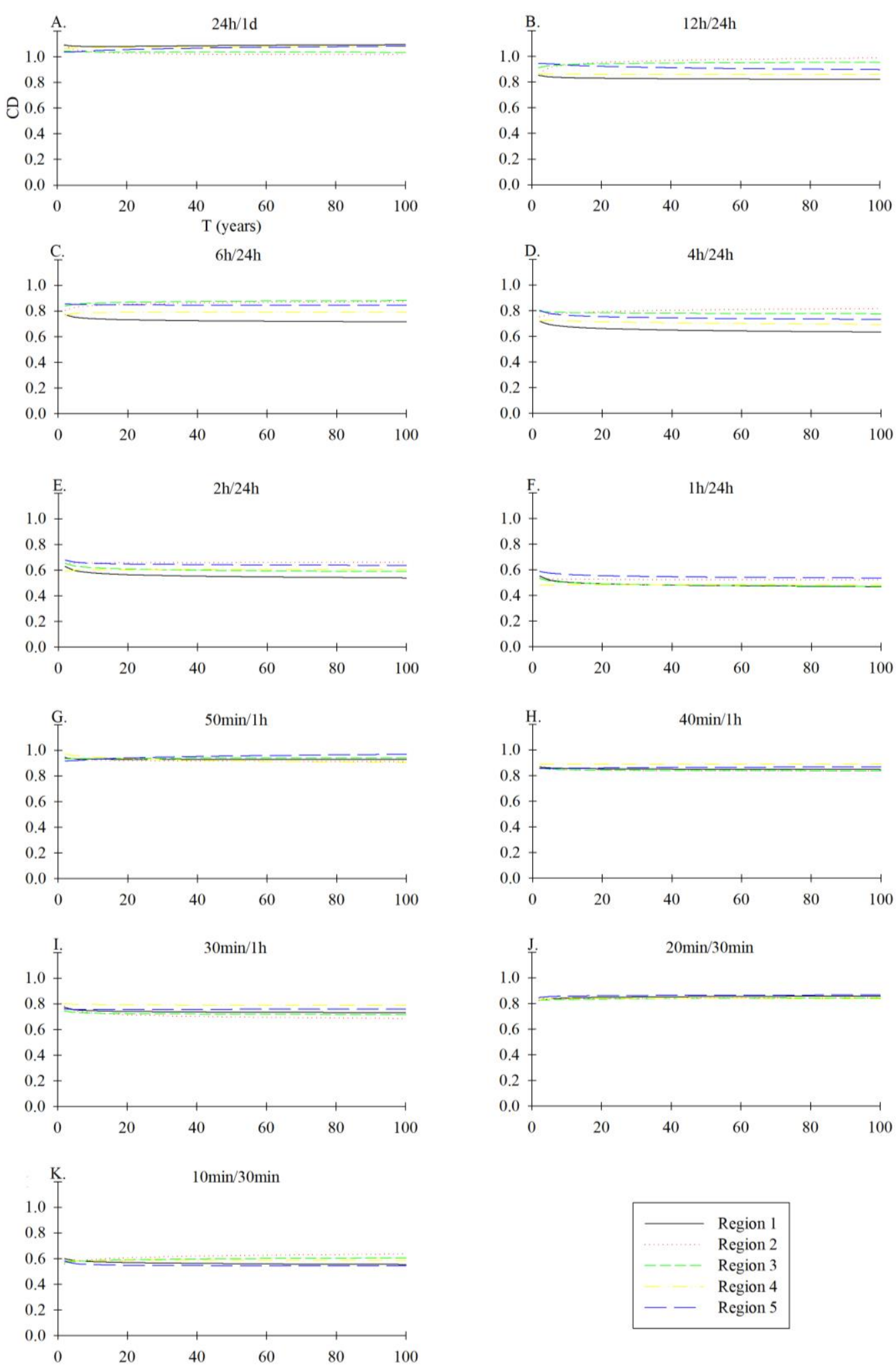

FIGURE 2. Daily rainfall disaggregation coefficients (CD) as a function of the return period for five homogeneous regions of the Doce river basin: 24h/1d (A), 12h/24h (B), 6h/24h (C), 4h/24h (D), 2h/24h (E), 1h/24h (F), 50min/1h (G), 40min/1h (H), $30 \mathrm{~min} / 1 \mathrm{~h}(\mathrm{I}), 20 \mathrm{~min} / 30 \mathrm{~min}(\mathrm{~J}), 10 \mathrm{~min} / 30 \mathrm{~min}(\mathrm{~K})$.

The statistical evaluation results show that the null hypothesis $\left(\beta_{1}=0\right)$ was not accepted for $50 \%$ of rainfall ratios of the five HHR indicating that half of the coefficients submitted to the test varied according to the return period (Table 7). 
TABLE 7. p-value results obtained by the Student's t-test, at a significance level of $5 \%$ with null hypothesis $\left(\mathrm{H}_{0}\right)$ for the rainfall disaggregation coefficients and the return periods.

\begin{tabular}{|c|c|c|c|c|c|c|c|c|c|c|c|}
\hline \multicolumn{12}{|c|}{ p-value (Student's t-test) } \\
\hline \multirow[b]{2}{*}{ HHR } & \multicolumn{11}{|c|}{ Rainfall disaggregation coefficients } \\
\hline & $\begin{array}{l}24 \mathrm{~h} \\
1 / \mathrm{d} \\
\end{array}$ & $\begin{array}{l}12 \mathrm{~h} \\
124 \mathrm{~h}\end{array}$ & $\begin{array}{c}6 \mathrm{~h} \\
124 \mathrm{~h} \\
\end{array}$ & $\begin{array}{c}4 \mathrm{~h} \\
/ 24 \mathrm{~h} \\
\end{array}$ & $\begin{array}{c}\mathrm{h} \\
/ 24 \mathrm{~h} \\
\end{array}$ & $\begin{array}{c}1 \mathrm{~h} \\
/ 24 \mathrm{~h}\end{array}$ & $\begin{array}{c}50 \mathrm{~min} \\
/ 1 \mathrm{~h}\end{array}$ & $\begin{array}{c}40 \mathrm{~min} \\
/ 1 \mathrm{~h}\end{array}$ & $\begin{array}{c}30 \mathrm{~min} \\
/ 1 \mathrm{~h}\end{array}$ & $\begin{array}{l}20 \mathrm{~min} \\
130 \mathrm{~min}\end{array}$ & $\begin{array}{l}10 \mathrm{~min} \\
130 \mathrm{~min}\end{array}$ \\
\hline 1 & 0.1681 & 0.0631 & 0.0524 & 0.0361 & 0.0539 & 0.0624 & 0.2343 & 0.0603 & 0.0888 & 0.0450 & 0.0341 \\
\hline 2 & 0.1232 & 0.0522 & 0.0446 & 0.0218 & 0.0064 & 0.0960 & 0.1429 & 0.1466 & 0.0460 & 0.1040 & 0.0200 \\
\hline 3 & 0.0911 & 0.0469 & 0.0427 & 0.0175 & 0.0439 & 0.0398 & 0.0021 & 0.0857 & 0.0603 & 0.0059 & $\mathbf{0 . 0 1 3 3}$ \\
\hline 4 & 0.0467 & 0.1531 & 0.2288 & 0.0027 & 0.1315 & 0.0382 & 0.0121 & 0.5325 & 0.0611 & 0.4321 & 0.0473 \\
\hline 5 & 0.0031 & 0.0055 & 0.0494 & 0.0446 & 0.0645 & 0.0269 & 0.0035 & 0.0014 & 0.6186 & 0.0617 & 0.1419 \\
\hline
\end{tabular}

This result is very relevant for the intense rainfall study, as the influence of return period in obtaining the disaggregation coefficients was not considered in the traditional study carried out by CETESB (1986). Martins et al. (2019) determined values of disaggregation coefficients for Caraguatatuba city (SP), by applying the Gumbel-Chow disaggregation methodology, and a variation in the return period is experienced, which also contradicts the CETESB (1986) premiss. Thus, the study result proves the importance of the use of specific rainfall disaggregation coefficients for each return period.

\section{CONCLUSIONS}

The regional rainfall disaggregation coefficients obtained for the entire Doce river basin were not adequate for the use in daily rainfall disaggregation studies. However, the division of the Doce river basin into five hydrologically homogeneous regions was effective for the purpose of using regional disaggregation coefficients for the respective regions. Therefore, the premise of similarity of these coefficients in different locations is contradicted; thus, a regional approach should be used whenever possible in studies of intense rainfall.

The return period has an obvious influence on the rainfall disaggregation coefficients and should be taken into account in study of intense rainfall using the daily rainfall disaggregation method.

Thus, the employment of specific daily rainfall disaggregation coefficients for the hydrologically homogeneous regions and according to the return period of each project is of great value for the correct dimensioning of hydro-agricultural projects that require information on heavy rainfall.

\section{ACKNOWLEDGMENTS}

This article is dedicated to the longing memory of Professor Silvio Bueno Pereira. The authors are thankful to the National Water and Sanitation Agency of Brazil for providing the database. This study was partially financed (PhD scholarship) by the Coordination for the Improvement of Higher Level Personnel (CAPES) - Finance Code 001; by the Brazilian National Council for Scientific and Technological Development (CNPq); and by the Foundation for Research Support of the State of Minas Gerais (Fapemig).

\section{REFERENCES}

Abreu MC (2018). Desempenho de métodos de desagregação de chuvas intensas. Tese Doutorado, Universidade Federal de Viçosa, Departamento de Engenharia Agrícola.

Alvares CA, Stape JL, Sentelhas PC, Gonçalves JLM, Sparovek G (2013) Köppen's climate classification map for Brazil. Meteorologische Zeitschrift 22(6):711-728. DOI: https://doi.org/10.1127/0941-2948/2013/0507

Aragão R, Santana GR, Costa CEFF, Cruz MAS, Figueiredo EE, Srinivasan VS (2013) Chuvas intensas para o estado de Sergipe com base em dados desagregados de chuva diária. Revista Brasileira de Engenharia Agrícola e Ambiental 17(3):243-252. DOI: https://doi.org/10.1590/S1415-43662013000300001

Back ÁJ (2020) Alternative model of intense rainfall equation obtained from daily rainfall disaggregation. RBRH 25. DOI: https://doi.org/10.1590/23180331.252020190031

Back ÁJ, Oliveira JLR, Henn A (2012) Relações entre precipitações intensas de diferentes durações para desagregação da chuva diária em Santa Catarina. Revista Brasileira de Engenharia Agrícola e Ambiental 16(4):391398. DOI: https://doi.org/10.1590/S141543662012000400009

Bielenki Júnior C, Barbassa AP, Miranda RB, Mauad FF (2016) Determinação de curva intensidade-duraçãofrequência por meio do emprego do método paramétrico de ajustamento de observações. Revista Brasileira de Climatologia 19:146-167.

Caldeira TL, Beskow S, Mello CR, Faria LC, Souza MR, Guedes HAS (2015) Probabilistic modelling of extreme rainfall events in the Rio Grande do Sul state. Revista Brasileira de Engenharia Agricola e Ambiental 19(3):197203. DOI: https://doi.org/10.1590/18071929/agriambi.v19n3p197-203

Cecílio RA, Pruski FF (2003) Interpolação dos parâmetros da equação de chuvas intensas com uso do inverso de potências da distância. Revista Brasileira de Engenharia Agrícola e Ambiental 7(3): 501-504.

CETESB - Companhia de Tecnologia de Saneamento Ambiental (1986) Drenagem urbana - Manual de projeto. CETESB, $464 \mathrm{p}$. 
Dorneles VR, Damé RCF, Méllo CFA, Teixeira-Gandra CFA, Ramirez MAA, Manke EB (2019) Intensityduration-frequency relationships of rainfall through the technique of disaggregation of daily rainfall. Revista Brasileira de Engenharia Agricola e Ambiental 23(7):506510. DOI: https://doi.org/10.1590/18071929/agriambi.v23n7p506-510

Genovez A, Zuffo A (2000) Chuvas intensas no Estado de São Paulo: estudos existentes e análise comparativa. Revista Brasileira de Recursos Hídricos 5(3):45-58. DOI: https://doi.org/10.21168/rbrh.v5n3.p45-58

Martins D, Gandini MLT, Kruk NS, Queiroz PIB (2019) Disaggregation of daily rainfall data for the Caraguatatuba city, in São Paulo State, Brazil. RBRH 24. DOI: https://doi.org/10.1590/2318-0331.241920180100

Naghettini M, Pinto ÉJDA (2007) Hidrologia estatística. Belo Horizonte, CPRM, 552p.

Ouarda TBMJ, Yousef LA, Charron C (2019) Nonstationary intensity-duration-frequency curves integrating information concerning teleconnections and climate change. International Journal of Climatology 39(4):23062323. DOI: https://doi.org/10.1002/joc.5953

Pereira DC, Duarte LR, Sarmento AP (2017). Determinação da curva de intensidade, duração e frequência do Município de Ipameri - Goiás. REEC Revista Eletrônica de Engenharia Civil 13(2):233-246. DOI: https://doi.org/10.5216/reec.v13i2.43330

Pereira SB, Nóia CPZ, Almeida RA, Coelho CD (2014) Method adjustment and equation set of maximum rainfall intensity, duration and frequency in the Mato Grosso do Sul State. Engenharia Agrícola 34(4):716-726. DOI: https://doi.org/10.1590/S0100-69162014000400011
Pfafstetter O (1957) Chuvas intensas no Brasil. Rio de Janeiro, Departamento Nacional de Obras de Saneamento, 419p.

PIRH-DOCE (2010) Plano integrado de recursos hídricos da bacia hidrográfica do rio Doce e planos de ações para as unidades de planejamento e gestão de recursos hídricos no âmbito da bacia do rio Doce. Consórcio Ecoplan-Lume, v1

Silva CB, Oliveira LFC (2017) Relação intensidadeduração-frequência de chuvas extremas na região nordeste do Brasil. Revista Brasileira de Climatologia 20:267-283. DOI: https://doi.org/10.5380/abclima.v20i0.49286

Silva DD, Pereira SB, Pruski FF, Gomes Filho RR, Lana AMQ, Baena LGN (2003) Equações de intensidadeduração-frequência da precipitação pluvial para o Estado de Tocantins. Engenharia na Agricultura 11(31):7-14.

Silva Neto VL, Viola MR, Silva DD, Mello CR, Pereira SB, Giongo M (2017) Daily rainfall disaggregation for Tocantins State, Brazil. Ambiente e Agua - An Interdisciplinary Journal of Applied Science 12(4):605. DOI: https://doi.org/10.4136/ambi-agua.2077

Sousa HT, Pruski FF, Bof LHN, Cecon PR, Souza JRC (2009) SiscaH 1.0: Sistema computacional para análises hidrológicas Brasília, Agência Nacional das Águas. Viçosa, Universidade Federal de Viçosa, 60p.

Valverde AEL, Silva DD, Pruski FF, Leite HG, Brandão VS (2003) Análise Regional de Chuvas Intensas para a Bacia do Rio Doce. Revista Brasileira de Recursos Hídricos 8(4):157-168.

Villela SM, Mattos A (1975) Hidrologia aplicada. São Paulo, McGraw-Hill do Brasil, 245p. 